\title{
A Cultural Perspective to Leadership Practices in Balkans
}

Nizamettin Doğar, PhD.

Çukurova University, Turkey

\begin{abstract}
Absract
The question of whether a single leader type will emerge as one of the possible effects of globalization has required research on the subject. In the context of culture, Hofsthede, Brodbeck et al, and GLOBE studies, revealing that different leadership characteristics come to the fore in different geographies with cultural influences, refuting the claim that a uniform leader model will emerge with globalization. Among the aforementioned studies, GLOBE studies went a little further and claimed that leadership is actually a function of culture.
\end{abstract}

Leadership research in the Balkans, which is a tangle of cultures with its complex ethnic structure, is relatively less included in the literature. The main purpose of this article is; Despite this problem arising from the Cold War period, how the leadership styles are in the Balkans is to examine the relationship between Balkan style leadership and culture. At the same time, the article has a secondary purpose that questions whether the claim that "there is not a single Balkans" is also valid for leadership practices when it comes to culture.

Literature review and observation method were used in the research. The observations mainly include the observations made in Albania between the years of 2012-2015. On the other hand,the literature review is based on the data obtained primarily from local studies about each country in the Balkans.

The results obtained emphasize that when it comes to leadership in the Balkan countries, the first thing is that political leadership is understood, which draws attention to autocratic leadership from the socialist administration period. In the context of business leadership, it shows that autocratic leadership was effective in the 10-year transition period after the Cold War, and that transformational leadership began to come to the fore in the 2000s at varying speed and rate according to institutions and countries. As a result of the investigations, the article shows that quite similar leadership characteristics stand out for the Balkans, the culture of democracy has not yet fully settled in this context, the avoidance of uncertainty in social codes, the autocratic administration still has an important place as a reflection of cultural dimensions such as the distance of power, on the other hand, willingness to change with new generations, more democratic leadership expectations increase and transformational leadership comes to the fore with the change in geography. 
Although the article has limitations in terms of containing observations specific to one country, it supports the claims in terms of including the local research results of the countries and is considered to contribute to the literature for the Balkans where limited research is available.

Keywords: leadership; Balkans; autocratic leadership; transformational leadership; culture.

\section{Introduction}

The concept of leadership is briefly used to guide, lead, leader, and counselor. Additional definitions are:

- When a member of a group or organization influences other members to achieve the goals of the organization or group, ${ }^{1}$

- The process by which one person influences and directs the activities of others to achieve certain personal or group goals under certain conditions, ${ }^{2}$

- The process by which one person influences and directs the activities of others to achieve certain personal or group goals under certain circumstances, ${ }^{3}$

- For the effectiveness and success of the organization of which a person is a member, to influence and motivate other employees in the organization and to make them sacrifice for the success and effectiveness of the organization. ${ }^{4} \mathrm{~A}$ wide range of definitions draw our attention.

When the definitions are examined, it is seen that generally three common points come to the fore. These can be summarized as;

- Existence of a specified purpose,

- The existence of a group of people who want to be mobilized towards this goal,

- The influencing process that should be applied to the human group to move in the desired direction ${ }^{5}$.

Although the first and second points above are common issues in leadership, the third feature, the "influencing process", highlights the issue of leadership styles. The question whether globalization will reveal a single type of leader necessitates the examination of the relationship between culture and leadership. Therefore, the article - in general will examine the leadership styles in the Balkan geography where different cultures

\footnotetext{
${ }^{1}$ M. Jennifer George and Gareth R. Jones (2008). Understanding and Managing Organizational Behavior. Pearson: Prentice Hall, Upper Saddle River, New Jersey, p.401.

2 Önder Barlı (2010). Davranış Bilimleri ve Örgütlerde Davranış, İstanbul: Aktif Yayınevi, p.355.

${ }^{3}$ Tamer Koçel (2010). İşletme Yöneticiliği. İstanbul: Beta Basım Yayım Dağıtım A.Ş., p.569.

${ }^{4}$ R. J. House \& M. Javidan (2004). Overview of GLOBE. In R. J. House, P. J. Hanges, M. Javidan, P. Dorfman, \& V. Gupta (Eds.) Culture, leadership and organizations: The GLOBE study of 62 societies (pp. 219-234). Thousand Oaks, CA: Sage.

${ }^{5}$ A. Tabak ve Ü. Sığrı (2014). Liderlik. Inside: Ü.Sığrı ve S. Gürbüz (Ed.), Örgütsel davranış (pp. 373-429), İstanbul, Beta Yayınları.
} 
live together, and in particular, will focus on the topic if there are different leadership styles for the Balkans or does the geography have some general leadership styles? This particular objective will also test the validity of Maria Todorova's "There is not a single Balkan culture, but there are many Balkan cultures and this is also true for Balkan identities." ${ }^{6}$ (2004: 176) perspevtive for leadership.

\section{The concept of leadership from a cultural framework}

Cultural approaches that predict that rules and theories about leadership will work differently for each country have come to the fore in recent studies. With the understanding that western-based practices in the field of management have different results and these differences are mostly caused by cultural influences after various international studies have been revealed, it has started to question the direction and intensity of these effects rather than whether they are cultural effects. In other words, there is a relationship between the concept of leadership and social culture that cannot be ignored. When we say social culture, the issue of international relations and international interaction that increases with globalization gains importance. Especially after the 2nd World War, the effects of globalization, which started to be seen and rapidly increased with the possibilities of technology, increased the interdependence of nations and enabled different nations to be in more communication, creating an understanding of the effect of cultural differences on leadership performance. This approach, which can be expressed as a global leadership understanding, is different from leadership understanding in local culture and claims that an approach that works in one part of the world may not always work on the other side. ${ }^{7}$

Therefore, it is necessary to dwell on the relationship of cultural dimensions with leadership. This point of view is important to understand the impact of the cultural characteristics of the Balkans on leadership practices in the region and will contribute to the comprehension of the subject. When we look at the cultural dimensions of Hofsthede, the issues that arise and briefly mentioned below are basically related to which culture expects and accepts what kind of leader. It is possible to summarize this perspective as "the rulers are the mirrors of the society" and to explain as "those who govern the society are there according to the expectations of the society" as required by the implicit leadership approach.

Power distance: Inequality between people/ groups is related to the solutions found to the fundamental problem. ${ }^{8}$ In cultures with high power distance, individuals respect

\footnotetext{
${ }^{6}$ Todorova, Maria (2004). What is or is there a Balkan culture, and do or should the Balkans have a regional identity?, Southeast European and Black Sea Studies, 4:1, pp.175-185.

${ }^{7}$ H. Kabasakal, A. Dastmalchian, G. Karacay and S. Bayraktar (2012). Leadership and culture in the MENA region: An analysis of the GLOBE Project, Journal of World Business, 47(4), pp.519-529.

${ }^{8}$ G. Hofsthede (2011). Dimensionalizing Cultures: The Hofstede Model in Context, Online Readings in Psychology and Culture, Article 8.
} 
their superiors and avoid criticizing them. In cultures with low power distance, it is natural to criticize and challenge superiors. ${ }^{9}$

Leadership is closely related to power, status and authority all over the world. Considering the cultural structures of societies, it is seen that the distribution of power and authority differs from society to society, and societies differ from each other in terms of tolerance to power distribution. ${ }^{10}$ For example Smith, Peterson and Misumi ${ }^{11}$ found that in societies with high power distance cultural characteristics, leaders act more adhering to rules and procedures. The acceptability of authoritarian leadership behaviors is also high in cultural structures where inequality in the distribution of power and authority is highly accepted. ${ }^{12}$ It is possible to summarize the subject as how power and status are divided in a society affects leadership behavior in that society. ${ }^{13}$ This statement is an important determination that should be emphasized in the approaches regarding leadership in the Balkans.

Uncertainty avoidance: It is about society's reaction to uncertainty about the future. ${ }^{14}$ Societies with high levels of uncertainty avoidance become anxious in unpredictable situations. Societies with low uncertainty avoidance are less aggressive and relatively tolerant in unpredictable situations. ${ }^{15}$

The uncertainty in society and cultural sensitivity towards this uncertainty have the effects associated with leadership. In societies where uncertainty is not welcome, followers obey their leaders and expect their leaders to display habitual behavior. Even if the leader wants to make some changes and even succeeds in these matters, the trust of the followers in the leader decreases due to the uncertainty created by the change. ${ }^{16}$ Again, in societies with low tolerance to uncertainty, the leader is expected to show closer attention, be more directive and give more frequent feedback. This may cause the leader to exhibit more task-oriented behaviors. ${ }^{17}$

\footnotetext{
${ }^{9}$ Erich B. Bergiel, Blaise J. Bergiel, John W. Upson (2012). Revisiting Hofstede's Dimensions: Examining the Cultural Convergence of the United States and Japan, American Journal of Management, Vol. 12(1), pp.69-79.

${ }^{10}$ See Hofstede, 1980, 2001.

${ }^{11}$ P.B. Smith, M.F. Peterson ve J. Misumi (1994). Event management and work team effectiveness in Japan, Britain and the USA. Journal of Occupational and Organizational Psychology, 67(1), pp.33-43.

12 D.N. Den Hartog, R.J. House, P.J. Hanges, S.A. Ruiz-Quintanilla \& P.W. Dorfman (1999). Culture specific and cross-culturally generalizable implicit leadership theories: Are attributes of charismatic/transformational leadership universally endorsed? The Leadership Quarterly, 10(2), pp.219-256.

${ }^{13}$ M.W. Dickson, D.N. Den Hartog \& J.K. Mitchelson (2003). Research on leadership in a cross-cultural context: Making progress, and raising new questions. The leadership quarterly, 14(6), pp.729-768.

${ }^{14}$ Hofstede (2011), Ibid.

${ }^{15}$ Bergiel et al., Ibid.

${ }^{16}$ J. Yan \& J.G.J. Hunt (2005). A Cross Cultural Perspective on Perceived Leadership Effectiveness, International Journal of Cross Cultural Management, 5(1), pp.49-66.

${ }^{17}$ M. Aktaş and A.S. Sargut (2011). İzleyicilerin Kültürel değerlerine göre liderliğe duyulan gereksinme nasıl farklılaşır?: Kuramsal bir çerçeve, Amme Idaresi Dergisi, 44(4), pp.145-163.
} 
Individualism/collectivism: It is related to the degree to which members of society are seen as individuals or members of a group. ${ }^{18}$ In a communitarian culture, the group's interests include the interests of the individual. People exhibit togetherness focused on a tightly bound lifelong relationship of commitment without questioning their loyalty to each other. ${ }^{19}$

Collectivism and individualism are also related to leadership and it is possible to see the interaction between leadership and culture in this relationship. For example, although top managers in individualist cultures are responsible for all success and failure, in collectivist cultures, even if the leader is the most important factor of success, rewarding or attributing success is made to the group or community. The gap in the salary differences of Japanese and American top managers can be expressed as an indicator of this situation. ${ }^{20}$ Jung and Avolio found that those with collectivistic tendencies achieved more successful results with transformational leadership, and those with individualistic tendencies with interactional leadership. ${ }^{21}$ The fact that paternalistic leadership behaviors, which are not widely accepted in individualist cultures because they are perceived as an intervention in private life, are more common in collectivist cultures is also important in understanding the relationship between culture leadership. ${ }^{22}$ Based on this theoretical information, we can say that the collectivism character of the Balkan culture required transformational leadership, which is supported by country-based analyzes.

Masculinity/femininity: Cultures in which dominant values ambitious, enthusiastic, competitive are called masculine cultures. On the contrary, in female cultures, friendly environment seeking, status security, physical security, etc. features stand out. ${ }^{23}$

Masculinity and femininity tendencies in a culture are also related to leadership behaviors in that culture. According to this, the leader type in the masculine cultures is determined, assertive and aggressive, while the leader in feminine cultures has less visible, accommodating and helpful features.

\footnotetext{
${ }^{18}$ G. Hofstede and M.H. Bond (1984). Hofstede's Culture Dimensions: An Independent Validation Using Rokeach's Value Survey, Journal of Cross Cultural Psychology, 15(4), pp.417-433.

${ }^{19} \mathrm{G}$. Hofstede (1997). Cultures and Organizations: Software of the Mind, 1st edition, McGraw-Hill, USA.

${ }^{20}$ C.M. Hampden-Turner \& F. Trompenaars (2008). Building Cross-Cultural Competence: How to Create Wealth from Conflicting Values, Yale University Press from Faruk Batır (2016). Türk Kara Kuvvetleri'nde Kültürel Yönelimler ve Liderlik İlişkisi, (Unpublished Master Thesis), Kara Harp Okulu Savunma Bilimleri Enstitüsü Savunma Yönetimi Ana Bilim Dalı, Ankara, p.46.

${ }^{21}$ D.I. Jung and B.J. Avolio (1999). Effects of leadership style and followers' cultural orientation on performance in group and individual task conditions. Academy of management journal, 42(2), pp. 208-218.

${ }^{22}$ Z. Aycan ve R.N. Kanungo (2000). Toplumsal Kültürün Kurumsal Kültür ve İnsan Kaynakları Uygulamaları Üzerine Etkisi. Inside: Z., Aycan (Ed.), Türkiye'de yönetim, liderlik ve insan kaynakları Uygulamaları (pp. 25-53). Ankara: Türk Psikologlar Derneği Yayınları.

${ }^{23}$ Geert Hofstede (2001). Culture's Consequences: Comparing Values, Behaviors, Institutions, and Organizations Across Nations (2nd ed), Thousand Oaks, CA: Sage Publications.
} 


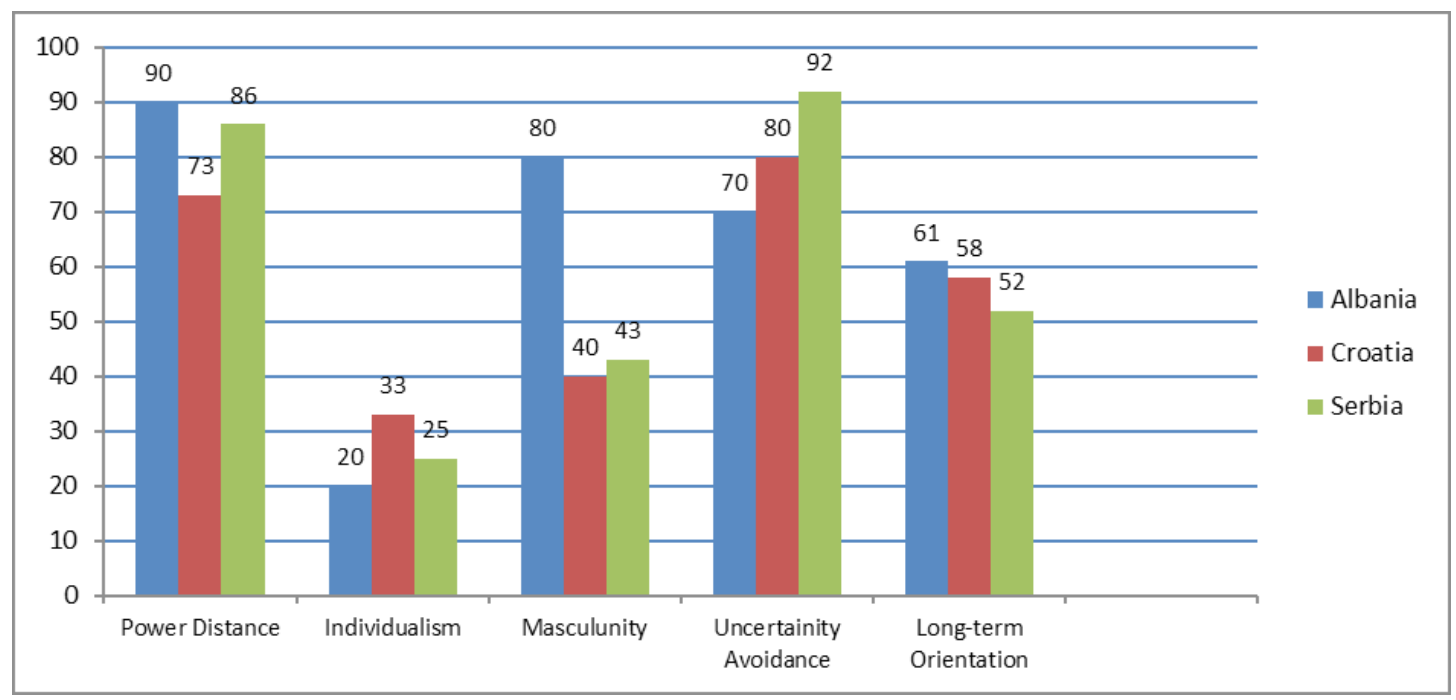

Source: Geert Hofstede, Gert Jan Hofstede, Michael Minkov, (2010). Cultures and Organizations: Software of the Mind. Revised and Expanded 3rd Edition. New York: McGraw-Hill USA ve Geert Hofstede, (2001). Culture's Consequences: Comparing Values, Behaviors, Institutions, and Organizations Across Nations. Second Edition, Thousand Oaks CA: Sage Publications ve Nizamettin Doğar (2016). Kültür, Kimlik, Etnisite ve Milliyet Kavramları Çerçevesinde Bat Balkanlar: Hofstede Perspektifi, The Journal of Academic Social Science Studies, Number: 52, Winter I 2016, p.410.

The first of the other two studies on culture that should be considered is the results of the survey conducted by Brodbeck et al. on 6052 subjects in 22 European countries. According to the aforementioned research, although leadership behaviors in today's global conditions should be addressed with a global overview, it should not be ignored that there are differences in leadership behaviors according to cultures and that priorities and orders of importance may vary. As a result of the researches carried out in 22 European countries across the north-west and south-east societies, credibility is the most important leadership characteristic in most of the north-west societies and especially in countries where German culture is dominant, and England, a strict and prescriptive European country, has the highest leadership. It is stated that the important feature is performance. Likewise, in the German and Scandinavian culture, reliability, vision, teamwork and performance ranking are at the top of leadership qualities, while the most important characteristics for leadership in French culture are the understanding of collaboration and leadership characteristics that are far from autocratic. ${ }^{26}$ According to the same study, when we look at the southern culture, it is seen that teamwork, sharing and managerial skills are prominent leadership characteristics, in Latin culture, especially in Italy (Italy is included in the Latin culture

\footnotetext{
${ }^{24} \mathrm{Ibid}$

${ }^{25}$ Hofstede and Bond, Ibid, pp. 417-433.

${ }^{26}$ See. Pınar Yeşilyurt (2007). Türk ve Italyan Yöneticilerinin Liderlik Tarzları: Türkiye'de Faaliyet Gösteren Türk-Italyan Ortak Girişimlerinde Bir Uygulama, Unpublished Masters Thesis, Çukurova Üniversitesi Sosyal Bilimler Enstitüsü İşletme Anabilim Dalı, Adana, pp.43-45.
} 
in the study. ND), performance, reliability and seeing the future are the primary characteristics after teamwork. It is stated as. Called the Near East, Turkey and Greece also found in the group, teamwork seen in classic southern-eastern societies counted most important feature, its stability, its future vision, reliability and creativity are followed. When we look at Latin and Turkish cultures together, we see that humancentered leadership approaches are more prominent in these two cultures that are close to each other. When we look further east, when we look at the survey results in Russia and Georgia, it is seen that managerial skills and determination are the most sought after characteristics in leaders. ${ }^{27}$

The second study, also from Turkey with the participation of scientists is working GLOBE. Among the basic research questions addressed within the scope of the GLOBE research, those related to leadership are expressed as follows: ${ }^{28}$

- Are there any leadership traits and behaviors that are cross-culturally valid?

- Are there leadership characteristics and behaviors unique to certain cultures?

- How do cultural characteristics affect the effectiveness and acceptance of certain leadership behaviors?

The basis of leadership understanding in GLOBE research is based on implicit leadership theory. According to the implicit leadership theory, people's minds have a scheme or pattern of leaders' traits and behaviors. Thanks to this model, individuals can easily distinguish leaders. Therefore, if the leadership model in a person's mind is known, it can be concluded that this person will evaluate who will be effective leaders. ${ }^{29}$ We can express this statement as leaders who are accepted in all cultures, including the Balkans, are people who meet the expectations of the subconscious cultural codes of the society.

As a result of the GLOBE research, six global leadership behavior definitions have emerged. These are defined as charismatic leadership, team-oriented leadership, participatory leadership, human-oriented leadership, autonomous leadership, and self-protective leadership behaviors. ${ }^{30}$ According to the data obtained from this comprehensive study, charismatic, team-oriented and participatory leadership styles are the most striking leadership approaches in Italy, Spain, Portugal and France, which are included in Latin European culture. ${ }^{31}$ Egypt, Kuwait, Qatar and Turkey that are included in the team focused on the Middle East countries according to the research results, it is seen to be effective charismatic leadership and participatory approach. According to the data obtained, the charismatic leadership approach is the most preferred model in

\footnotetext{
${ }^{27}$ See. Yeşilyurt, Ibid, pp.45-47.

${ }^{28}$ See. Battr, Ibid, pp.40-43.

${ }^{29}$ R.J.House, P.J. Hanges, S.A. Ruiz-Quintanilla, P.W Dorfman, M. Javidan, M. Dickson and V. Gupta (1999). Cultural Influences on Leadership and Organizations: Project GLOBE. Advances in Global Leadership, 1(2), pp. 171-233.

${ }^{30}$ House vd, agm,

${ }^{31}$ Yeşilyurt, age, s.46.
} 
Italy. In Turkey's approach to the defending team-oriented leadership approach that is the most important way to achieve success in unifying the collaboration and team work it is seen as more preferable. ${ }^{32}$ Kabasakal ve Bodur (2007) qualitative study conducted in the context of the GLOBE study autocratic leadership style predominantly observed in Turkey, stated that it is paternalistic and consultative leadership style..$^{33}$ When we look at the Balkan countries in the Eastern Europe category, it is seen that Albania, Greece, Hungary and Slovenia are included in the research. In other words, the problem of reaching empirical data for all of the Balkans, which we have expressed in different places, shows itself here as well. Within the framework of the research, we see that participatory leadership emerges as a less important type of leadership in Eastern European culture compared to countries in the Anglo Saxon, German European and Northern European group. ${ }^{34}$ We can express this as Eastern European culture, which includes 4 Balkan countries, adopts less participatory, therefore more centralized and autocratic-oriented leadership styles, which gives us important clues about the Balkanstyle leadership, which we will focus on in the following sections.

\begin{tabular}{|c|c|c|c|c|}
\hline Anglo & Latin European & Latin America & $\begin{array}{l}\text { Germanic } \\
\text { European }\end{array}$ & Eastern Europe \\
\hline $\begin{array}{l}\text { America } \\
\text { Canada } \\
\text { England } \\
\text { Ireland } \\
\text { New Zealand } \\
\text { South Africa }\end{array}$ & $\begin{array}{l}\text { France } \\
\text { Israel } \\
\text { Italy } \\
\text { Portugal } \\
\text { Spain } \\
\text { Switzerland } \\
\text { (French Speakers) }\end{array}$ & $\begin{array}{l}\text { Argentina } \\
\text { Bolivia } \\
\text { Brazil } \\
\text { Colombia } \\
\text { Costa Rica } \\
\text { Ecuador } \\
\text { El Salvador } \\
\text { Guatemala } \\
\text { Mexican } \\
\text { Venezuelan }\end{array}$ & $\begin{array}{l}\text { Austria } \\
\text { Germany-East } \\
\text { Germany-West } \\
\text { Netherlands } \\
\text { Switzerland }\end{array}$ & $\begin{array}{l}\text { Albania } \\
\text { Georgia } \\
\text { Greece } \\
\text { Hungary } \\
\text { Kazakhistan } \\
\text { Poland } \\
\text { Russia } \\
\text { Slovenia }\end{array}$ \\
\hline Southeast Asia & $\begin{array}{c}\text { Sub-Saharan } \\
\text { Africa }\end{array}$ & Middle East & North Europe & Confucius Asia \\
\hline $\begin{array}{l}\text { India } \\
\text { Indonesia } \\
\text { Iranian } \\
\text { Malaysia } \\
\text { Philippines } \\
\text { Thailand }\end{array}$ & $\begin{array}{l}\text { Namibia } \\
\text { Niger } \\
\text { South Africa } \\
\text { Zambia } \\
\text { Zimbabwe }\end{array}$ & $\begin{array}{l}\text { Egypt } \\
\text { Kuwait } \\
\text { Morocco } \\
\text { Train } \\
\text { Turkey }\end{array}$ & $\begin{array}{l}\text { Denmark } \\
\text { Finland } \\
\text { Sweden }\end{array}$ & $\begin{array}{l}\text { China } \\
\text { Hong Kong } \\
\text { Japan } \\
\text { Singapore } \\
\text { South Korea } \\
\text { Taiwan }\end{array}$ \\
\hline
\end{tabular}

Table-2: Clusters to Which Countries Are Included According to the GLOBE Survey

Source: V. Gupta and P.J. Hanges (2004). Regional and Climate Clustering of Societal Cultures. In R. J. House, P. J. Hanges, M. Javidan, P. Dorfman ve V. Gupta (Eds.), Leadership, culture, and organizations:

The GLOBE study of 62 societies (pp. 178-215). Thousand Oaks, CA: Sage from Batrr, Ibid, p.26.

\footnotetext{
32 House vd., age, ss. 685-697.

${ }^{33}$ Batir, age, s.41.

34 Ümit Ercan (2010). Liderlerin Kültürel Değer Yönelimleri ve Değerlerin Liderlik Sürecine Etkileri: Türk ve ABD Yöneticileri Üzerine Karşılaştırmalı Bir Araştırma, Yayımlanmış Yüksek Lisans Tezi, Kara Harp Okulu Savunma Bilimleri Enstitüsü Savunma Yönetimi Ana Bilim Dalı, Ankara 2010.
} 


\section{Method}

Literature review and observation method were used as methods in the study. The observation method was mostly utilized from the observations made in Albania between 2012-2015, additionally from time to time it was used in the observations of Macedonia, Serbia and Greece. In the literature review, the researches conducted within the framework of Balkan countries have been used.

\section{Discussion}

\section{Balkans and Leadership}

Two points draw attention in the leadership studies regarding the Balkans:

1. In the Balkans, academic studies about modern management in general and leadership in particular started to be seen since the beginning of 2000s, and quality and field studies based on regional studies were only started after 2010,

\section{Lack of empirical data to cover the entire geography of both periods.}

As we mentioned above, modern management science and leadership research in the Balkans requires a focus on recent history. It is a new period after 1989 because most of the countries in the region are members of the Eastern Block or apply socialist ideology. The system, which has been applied for 45 years, has affected all areas of life and constituted an obstacle to the modern development of institutions in the countries of the region and caused the establishment of Soviet-style autocratic management and leadership. With the end of the Cold War and the collapse of the Eastern Block, the Balkan countries that were left in a vacuum emerged. The overthrow of the governments one by one left behind a complete chaos. In countries that have been managed with a closed system for years, there is no institutional infrastructure as they enter the new era, everything has been controlled by the state. Both the governing elites at the state level and the organizations that are under the control of the state and managed without the logic of commercial business suddenly disappeared. Therefore, it is necessary to recover the debris left behind by the collapsed system and reconstruction.

Feichtinger and Fink determine that "in Eastern Europe, what cultures generally associated with communist heritage experience during the transition process is a cultural shock." ${ }^{\prime 35}$. Cultural shock, which is called as a reaction when faced with a different culture, is a reality that has been experienced intensely in the countries of the region after the Cold War. We can easily claim that the phenomenon, which is also known as collective cultural shock by expanding a little more, affects the management

${ }^{35}$ See. C. Feichtinger \& G. Fink (1998): The Collective Culture Shock in Transition Countries -Theoretical and Empirical Implications. Leadership \& Organization Development Journal. Vol. 19 Iss: 6, pp. $302-308$. 
functions. Therefore, the transition from a closed system originating from culture and lasting for 45 years to another open and new system was painful and took time. In the process that progressed in the form of understanding, adapting and applying the new system, the resistance arising from past habits and natural human behavior was added to this, and the pains increased. Therefore, all these paradigms oblige us to examine the issue of leadership in the Balkans sample from the perspective of political and then management functions. In order to examine the political leadership, it is necessary to go back a little further and focus on the dominant leadership styles seen in the historical process. In this study that we will be doing since the beginning of the 20th century, what draws our attention is the tendency of kingdom-like structures to continue in the Balkan geography, while new management styles identified with democracy emerged and gained weight in the western world. The general character of these administrations is that they are one-man and autocratic. In fact, we can argue that this situation does not grin too much, considering that there were similar governments in many countries outside the Anglo-Saxon tradition in the period between the two World Wars. In other words, the increasing nationalism discourses highlighting the doctrine of National Socialism in Germany and Italy and the heroized Hitler, Mussolini, Stalin in Russia and Hirohito in Japan in the same period are in line with this thesis. When we add to these the tradition of kingdom and one man in the Middle East, which is still continuing, the number of examples increases. Therefore, if we repeat the above sentence, the autocratic administration tradition seen in the Balkans between the two world wars is seen as a form of administration suitable for the majority. In this context, the understanding of democracy and the parliamentary system, which have come a long way in countries such as England, France and the USA, are not even in their infancy for other geographies, and we can argue that in this period, the management and leadership styles in the Balkans did not differ much, at least visually, compared to neighboring geographies.

When we look at the Cold War period after 1945, we come across a different picture. As an Eastern Bloc country, the political leadership of the countries in the region is in a rapid move away from the west. To put it again, while democracy and democratic leadership styles are rapidly developing and becoming popular in Western Europe, the Balkan countries have a character in which the autocratic leader typing has no alternative with an extremely rigid and centralized administration within the Eastern Bloc. Although the example of Yugoslavia and Tito, which we can call a relatively exception to this, has semi-democratic characters in itself, it is not outside of the single man and autocracy pattern in the big picture. The situation for the ruling and leader class is as follows: With the establishment of communist governments, the seizure of all the property of middle class property owners has caused changes in many professions. The lucky ones had the opportunity to find jobs as managers in state institutions, others joined the working class. Professionals such as doctors and 
engineers became government employees. Therefore, this situation resulted in the ruling class to be under the control of the state, which means the emergence of a uniform leader pattern in the administration. In other words, in the eastern bloc countries where the practice of communism is effective, the strict centralist and autocratic leader type is seen in every institution.

With the collapse of the Eastern Block, it is seen that the governments in the Balkan countries have changed one after the other with the domino effect. First, the dismissal of the socialist leaders and parties in a way, then the arrival of a person who grew up in the old system but has the flexibility to adapt to the new system and the following reforms are remarkable. The new characters seemingly represent a break from the east, a reunion with western institutions and values, and reconciliation. At this point, the first feature of change emerges in the Balkans. This feature, which can be expressed as the task of transforming institutions in a society turning from east to west, emerges as the new mission of the leaders. However, the paradox here is that the leaders who will make the transformation are themselves a part and product of the previous system.

The second feature is that the new figures lack experience and knowledge in democratic infrastructure, institutional transformation and modern leadership. This means that the first act in the name of change is unconditionally denigrating the old, and all the institutions of the past are quickly removed without overestimating the future. We mentioned above that the consequences of such practices are chaos and confusion. Here, the difference between countries depends on the flexibility of new leaders to make this transformation. As a part of this flexibility, the fast contact of the rulers with the west is directly proportional to their ability to persuade the west to achieve transformation and the support they can receive in structuring countries according to the new conjuncture.

In the real sense, it took time to establish democratic institutions and to reach modern types of leaders and managers. We can say that the period of about 10 years after the dissolution of the Eastern Block is the stage of recovery in the Balkan countries, overcoming the chaos and crises that have occurred. Of course, it is meant that the end of the 10-year period, new types of institutions, managers and leaders are just beginning to be seen. Because, according to the changing conjuncture, the growth of a new generation means an average of 20 years. This shows that the 2010 s should be waited for administrators and leaders with western education in the Balkan countries to be effective, or at least to work in institutions. This is exactly the situation seen in the examination made in the context of countries below, and modern management studies that started to be seen and increased after the 2010s support this claim.

The third feature is the influence of the west on change. First of all, it is seen that change and transformation are occurring faster in countries where Europe and then 
the USA prioritize support for regional interests. Significant steps have been taken to accelerate the process by training people through practices such as membership to regional and international organizations and exchange programs through inter-agency cooperation. This situation related to the strategic positions of the countries also explains the difference in terms of democratization between Romania and Albania, Croatia and Macedonia in geography. Of course, every country has the degree and speed of moving away from the Soviet bloc, which is undoubtedly an important factor in the difference in the previous sentence.

A fourth feature is the role of international companies. Although reasons such as regional stability and problems arising from governments (corruption, legal regulation, problems in the justice mechanism) are not very attractive for international investment, factors such as low labor cost and proximity to raw materials have provided investment opportunities for companies that like risk in the Balkans. It draws attention in the observations made in the region, where western capital companies operate with their own managers, which started to open up one by two in the countries of the region after the first 10 years of confusion.

The general picture we have cited so far is certainly not a template, and each country has its own differences. Therefore, the examination to be made on the basis of countries below will draw a general framework to reveal the country-specific conditions in this regard.

\section{Albania}

A study on Albania that draws attention to the use of power in organizations gives clues to the perception of the relationship between leadership and power in the country. ${ }^{36}$ The research, which examines the role and effect of power in terms of leaders and followers, includes the results of field research conducted in 30 companies with the questioning made through followers, since it is not possible to measure the power of the leader. The study, which has a perspective that sees leadership and power as equivalent, takes place in the approach of "no leader without power", but it is emphasized that effective leadership is not about having power, but how the leader uses power. ${ }^{37}$

The authors draw attention to Albania and the determination that "when the leader in Albania is mentioned, the political leader is understood and this is due to the habit of the past" is an information that can be generalized for many countries in the Balkans. Again, the determination that there is a limited number of publications on organizational leaders in Albania, and that new leadership programs have just started

${ }^{36}$ Adem Zogjani, Shyqyri Llaci \& Erida Elmazi (2014). The Role of Power in Effective Leadership and Followership: The Albanian Case, Romanian Economic and Business Review, Vol. 9, No. 1, pp.89-103.

${ }^{37}$ See. Ibid, p.92 
in universities ${ }^{38}$ supports our claim that "leadership studies are still new". Because, this claim overlaps with the thesis that the concepts and practices of organizational manager and leader in the Balkan countries mentioned above indicate the post-2010 period. It should be noted that Albania's being the last country to end the communist regime in Eastern Europe is an additional factor in this delay.

In the post-Cold War transition period, the situation is even more difficult for managers and leaders. Young managers have to do everything from the very beginning in the new period when they start without infrastructure and knowledge. In the society, which has a hierarchical structure and understands party leadership when the word leader is mentioned, an autocratic structure and leader type, which has gathered all the power in its hands, is seen as a symbol of authority, where followers only follow orders, is valid. ${ }^{39}$ Transforming all these paradigms into institutions and practices associated with democracy and modern leadership should be the goal of new types of leaders. However, this is an effort that takes time and effort. Because the leader in the country with the habit of the past; it is the name of authority and dominance. The rest are masses who follow orders, lack power, and consider themselves worthless. And in this paradox, it will not be easy to accept the type of leader whose power has diminished with new paradigms in the country, or who are far from the use of power in the classical sense.

Today, the organizational structure of Albania-based enterprises still consists of simple and small businesses. ${ }^{40}$ Cafes located on almost every corner in the country, hotels, restaurants / bar concepts, which are also quite common, are the most popular business types for Albanians. However, the existence of a significant amount of foreign investment should not be ignored. In the observations we made in the region, it was seen that as of 2015, a significant amount of international foreign companies are doing business in the country. Therefore, the concept of leadership and the need for a leader in the business world is at the highest level as of today. From the perspective of local entrepreneurs, it is seen that the business environment in the country is under the monopoly of a limited number of enterprises and the power is centralized in their hands.

Within this framework, if we want to summarize the general situation in the country, it is seen that formal methods are still applied in many companies and that power remains central in the hands of the leader. The high tendency of social culture to avoid uncertainty (Table-2) is also reflected in the businessenvironment. It seems that Albanian leaders tend to control everything in order to avoid uncertainty. ${ }^{41}$ In addition, it can be

\footnotetext{
${ }^{38}$ Ibid, p.93

${ }^{39}$ Ibid, p.94

${ }^{40}$ lbid, p.94

${ }^{41}$ lbid, p.98.
} 
stated that the country's masculine culture (Table-2) is reflected in the management functions. In masculine cultures, ambitiousness, assertiveness, and being competitive are the dominant values. Therefore, the competitive and bellicose environment we observe in every field, especially in the political field, overlaps with the literature. Hotel, restaurant, cafe / bar etc. Service sector enterprises and small manufacturing industries and factories are under the control of Albanian administrators, and most of them are managed in traditional ways. Countries, in particular Turkey, Italy, Greece and Austria special in doing business hotel chains, banks, telecommunications firms, and large industrial enterprises and institutions such as the mining sector is governed by leaders and CEOs who implement modern management style. Albanian executives working within these companies are also trained in this field.

\section{Romania}

The first of the researches that we will conduct our analysis about Romania is the study by Raluca Elena Hurduzeu, where emphasis is placed on bureaucratic and entrepreneurial leadership in terms of leadership in Romania. While bureaucratic leadership is valid for state institutions, entrepreneurial leadership is valid for companies that started operations after 1989 and are mostly private. According to the research, while the effects of the socialist system continue in management theory, transformation is also mentioned. Therefore, in the transformation process, more people, less performance-oriented, more team-based, more bureaucratic, less risktaking and participatory leaders are encountered. ${ }^{42}$

In fact, the situation in question is not different for other leaders in the region. All communist leaders who seized power in the Balkans after the Second World War, gradually gathered all the power in hand and displayed autocratic rule. Simultaneously, as a requirement of socialism, all private sector enterprises were transferred to the state and personal enterprise was prevented. It is clear that this means that there is no alternative other than transferring all authority to state institutions in terms of business management and autocratic leadership.

There are other studies on various aspects of the transition period from the socialist system to the liberal system in the country. It is noteworthy that most of the studies show that managers and subordinates prefer autocratic management. ${ }^{43}$ On the other hand, another study by Steyrer, Hartz, and Schiffinger emphasizes transformational leadership by drawing attention to new generation leader behaviors. ${ }^{44}$ When these two findings are combined, it becomes clear that it is necessary to draw attention

\footnotetext{
${ }^{42}$ See. Raluca-Elena Hurduzeu (2015). Culture and Leadership: The Case of Romania, The Romanian Economic Journal, Year XVIII, No.56, pp.119-134.

${ }^{43}$ V. Edwards \& P. Lawrence (2000) Management in Eastern Europe, UK: Houndsmill.

${ }^{44}$ See Johannes Steyrer, Ronald Hartz and Michael Schiffinger (2006). Leadership in transformation - between local embeddedness and global challenges, Journal of East European Management Studies, Vol. 11, No. 2, pp. 113-139.
} 
to traditional and transformational leadership styles in the Romanian sample. While the first of these refers to the leadership practice and autocratic management from the past, the second reveals the existence of transformation, change and modern leadership practices in modern private sector enterprises.

In Luca's research cited in the first research, reference is made to the Hofstede perspective and it is revealed that Romania has similar values with other Balkan countries: high power distance, high socialism, femininity, high uncertainty avoidance, short-term focus. In other words, Romania, like other Balkan countries, is positioned differently from Anglo-Saxon countries. What Luca emphasized is that in traditional Romanian organizations the main goal is not performance but intergroup loyalty and cooperation. If the desire to achieve the goals threatens the safety of employees, this situation will soon become a political instrument, politicize the organization and cause internal conflict. In the same research, the search for the most appropriate leadership behavior with European countries and the Romanian system also yields interesting results. Ideal leadership scenario for Romanians; it is British in structure and French or German style in processes. French-style management behavior in the building does not fit Romanians, as this pattern reminds Romanians of autocratic rule of the past. ${ }^{45}$

Finally, it is worth mentioning the research conducted by Aioanei, which reveals a leadership analysis of four styles and two dimensions. In the study in question, it is concluded that Romanian managers are more autocratic, they are not inclined to participatory leadership style, and subordinates' participation in decisions is not welcome, and it is seen that the prominent leader behavior is the "military leader" type. In a study conducted among young people, it is found that the young generation tend to be more democratic leaders.

\section{Bulgaria}

It is noteworthy that the studies for Bulgaria are scarce. In this context, the article by Kiril Todorov and Iliya Kereziev examining the "leadership transfer in family companies in Bulgaria" that we could reach, contains especially the views and data regarding the transition to democracy. The authors state that the entrepreneurs operating in the first decade of the establishment of democracy in the Bulgarian business environment transferred control of their companies in the following decade. ${ }^{46}$ This determination gives us the opportunity to follow the transformation in the country, albeit partially. That is to say, the entrepreneurs doing business with classical and traditional methods in the first decade, when they were inadequate to adapt to the changing conditions in the country, transferred their companies to their new owners.

\footnotetext{
${ }^{45}$ See A. Luca (2005) Employeescu, O scurtă caracterizare a angajatului roman, Bucureşti, Editura Interact, akt. Raluca-Elena Hurduzeu, Ibid, p.128.

${ }^{46}$ Bkz. Kiril Todorov \& Iliya Kereziev (2013). Leadership Transfer and the Successors Preparation in Bulgarian Family Enterprises, Economic Alternatives, Issue 2, pp.5-20.
} 


\section{Serbia}

In our research, we saw that Serbia also has a relatively rich academic background in leadership work. The study by Živka Pržulj and Gordana Vukelić questioning the cultural barriers in front of Serbia's joining the EU gives important clues in terms of our topic. ${ }^{47}$ In the study, which touches on the effect of national culture on behavior, decision making and problem solving methods in society, especially the relationship between leadership and motivation is mentioned. The striking aspect of the study, which is mentioned that Serbia is a country in the transition period, is that the relations between the cultural dimensions of Hofsthede and the management functions have been examined specifically for Serbia, and attention has been drawn to the role of cultural differences in the delayed EU membership.

When looking at the cultural dimensions of the states within Yugoslavia in Hofsthede's research; high power distance and a tendency to avoid uncertainty, low individuality and masculinity, and a medium-level long-term focus. In their analysis, the claim that these features have negative effects on the development of the democratic society and market economy, especially in the EU integration process, "the high power distance has many negative effects for Serbia" is noteworthy. ${ }^{48}$

The high uncertainty avoidance dimension has the feature that prevents change in the society. The general character of such societies; they do not accept a change gradually and reject partial changes. This situation does not work and continues until the revision becomes mandatory. ${ }^{49}$ Serbia is a country that rejects political and economic change. Therefore, this situation is also effective in the EU membership process.

According to the theory, there is an inverse relationship between power distance and leadership style. In the research, it is stated that authoritarian leadership style is preferred in cultures with high power distance such as Serbia. In such cultures, change in power structure does not mean a new distribution of power, but a change in someone else with power and with the same behavioral patterns. ${ }^{50}$ So, people change, but the power of the leader is always high. In societies with a high power distance, the determination of the proportional relationship between power distance and corruption, where certain power holders destroy the system by going beyond the laws and norms, are shown as the obstacles in Serbia's EU membership process.

In organizations with high power distance, there is a tendency to expect obedience to supervisors. The boundaries between those who have power and status and those

\footnotetext{
${ }^{47}$ See. Živka Pržulj \& Gordana Vukelić (2011). Cultural Barriers to Serbia Joining the European Union, pp.118-132, Inside: Mirjana Radovic Markovic \& Srdjan Redzepagic \& João Sousa Andrade \& Paulino Teixeira (ed.), 2011. "Serbia and the European Union: Economic Lessons from the New Member States," Books, Institute of Economic Sciences, edition 1, volume 1.

48 Ibid, p.128.

${ }^{49}$ Ibid, p.130.

${ }^{50}$ Nebojša Janićijević (2008). Organizaciono ponašanje, Datastatus, Belgrad, akt. Raluca-Elena Hurduzeu, Ibid, p.128.
} 
who do not are sharply defined. Power in such organizations; It is the main factor that ensures the organizational order and determines the roles. Information is under control, a limited number of employees have access to resources, promotions and awards. Organizations with low power distance prefer participatory relations and equal rights and use legal power rather than coercive power. ${ }^{51}$ In Serbia, promotion to higher levels in the management hierarchy, especially in state-run companies, is not only dependent on the decision of upper-level leaders, but also depends on the approval of the political authorities, with the habit of the socialism tradition..$^{52}$ Another result of the same research is the finding that personal goals are less important for Serbian middle-level managers than common organizational goals, which should be found in the long socialism period.

When we look at another cultural dimension, individuality, we see that societies with low individuality values are weak in terms of success and social motivation. In other words, there is a negative relationship between low individuality and achievement and motivation..$^{53}$ While individual cultures promote individual responsibility and success, loyalty and obedience are important in communitarian cultures. Individual cultures are more free in human rights and freedoms. In cultures where the individual is at the center, freedom, which is seen as an individual's right, is an indispensable value. However, in socialist cultures, it is possible to pass away from individual rights for the benefit of society or the group.

Serbia has relatively low masculine values, that is, it is a female culture. Female culture means that relationships develop on a more emotional basis and rationality is relatively weak. This occurs in the form of embracing the habits of the past more easily, rather than confronting the pragmatist realities specific to the country.

The future-orientation dimension is related to future planning and commitment. While high future-oriented and future-oriented living means planning, societies in which this dimension is low are more related to the past and the cultures related to the past. Serbia is a society that is emotionally connected to its past with its low future orientation. This prevents the country from establishing a rational relationship with its environment and prevents it from preparing itself for the future. ${ }^{54}$

Another study conducted specifically in Serbia is the research that examines the dimensions of GLOBE organizational culture and job satisfaction and leader - member exchange with 256 mid-level managers working in organizations operating in the

\footnotetext{
${ }^{51}$ House et al. 2004

${ }^{52}$ Raluca-Elena Hurduzeu, Ibid.

53 lbid, s. 130.

${ }^{54} \mathrm{Ibid}, \mathrm{s} .131$
} 
country. ${ }^{55}$ In the article referring to the phrase "social cultural shock" mentioned above, the features of Serbia originating from its unique socialist system applications and which are not seen in other Soviet satellite countries are mentioned. The authors talk about the participatory and self-governing system of Serbia and the harmony of country-specific advisory councils with the paternalist leadership style. At the end of all these parameters, they claim that Serbia adapts to western-style management functions more quickly than other Soviet satellite countries. ${ }^{56}$

The importance of the family in Serbian society emphasized in the same research, the strength of family ties and the way this is reflected in organizations are remarkable. The higher expectation values about intra-group communalism (the current value is 4.56, while the required / desired values are 5.61), which is obtained in the study, reveals that a higher rate of communitarianism is expected in Serbian society. After the determination that this expectation originates from tradition and emphasizes family ties, it is noteworthy that the relationship is attributed to the "compulsory relationship" established between the employee and the organization, which is due to the fact that many employees have been in the same workplace throughout their lives during the time of socialism, and thus the sense of belonging that has become stronger over time.

In the final analysis, since the early 2000s, the liberalization of the economy and the democratization of politics have led to changes in the organizational culture in Serbia. However, some habits from the past still persist, such as high power distance. The rapid development in the product range, technology and competitive environment has also made it necessary to change. Therefore, the results obtained in the research conducted within the framework of GLOBE showed that middle-level managers are aware of the high level of future focus, which can be interpreted as being ready for change. ${ }^{57}$

\section{Macedonia}

In the study we conducted in the context of our study examining the leadership styles in Macedonian companies, we see that two factors that we have emphasized so far stand out. The first of these is that the determination that dominant leadership practice in the Balkans is autocratic is also valid for Macedonia. The second is the findings that autocratic management style is affected by age, gender, education level and duration of work experience, and these findings lead us to the second assessment that the themes of change and transformation come to the fore with the new generation. ${ }^{58}$

\footnotetext{
${ }^{55}$ See. Jelena Vukonjanski, Milan Nikoli, Olga Hadži, Edit Terek \& Milena Nedeljkovi (2012). Relationship between GLOBE organizational culture dimensions, job satisfaction and leader-member exchange in Serbian organizations, Journal of East European Management Studies (JEEMS), pp. 333-368.

${ }^{56}$ See. Ibid, pp. 334-335.

${ }^{57}$ Age, s.356

${ }^{58}$ Bkz. Marjan Bojadjiev, Ninko Kostovski \& Katerina Buldioska (2015). Leadership Styles in Companies from Republic of Macedonia, Economic Development, Vol.17 Issiue.3, pp.211-222.
} 
The main factor that will shape the future of organizations is the quality of leadership. However, it is not possible to treat this as an individual achievement alone. Because in this success, the importance of the leader to understand the values of the individuals in the organization and to establish a healthy communication with the individuals cannot be ignored. We can summarize this as understanding the culture of the leader and establishing a healthy communication accordingly is essential for the success of the organization. At this point, in his research examining Macedonian companies in the context of organizational culture, Popovski points out that there are three different types of organizational culture and calls them traditional, entrepreneurial and flexible. For him;

- In what he traditionally calls companies, there is a vertical hierarchy and a sharp division of labor, decisions are central and communication is in the form of directives and orders from top to bottom. The leadership style applied is autocratic.

- Entrepreneurial companies have the ability to better adapt to changes, but in terms of leadership style, these companies also tend to have an autocratic leadership style. The general characteristic of such companies is that they are strongly influenced by the founder. The informal relationships and rules established by the company owner are effective. They are market oriented companies and have the ability to adapt quickly to changing market conditions.

- In companies where flexible cultures are effective, people are valued according to their expertise and abilities. Leadership is participatory. The flexible structure of the organizational culture allows employees to adapt their behavior to new goals, production engines, technology and environmental factors. Relationships between staff are shared and there is a high group cohesion. This culture is key to the success of companies in new and knowledge-based economies. Hierarchy makes little sense and employees are valued for their talents and abilities. ${ }^{59}$

\begin{tabular}{|l|c|c|c|c|c|c|}
\hline $\begin{array}{c}\text { Preferred } \\
\text { Organizational } \\
\text { Culture }\end{array}$ & \multicolumn{2}{|c|}{ All Participants } & \multicolumn{2}{c|}{ Male Participants } & \multicolumn{2}{c|}{ Female Participants } \\
\hline Traditional & 19 & $39 \%$ & 11 & $39 \%$ & 8 & $36 \%$ \\
\hline Entrepreneur & 17 & $33 \%$ & 8 & $29 \%$ & 9 & $41 \%$ \\
\hline Flexible & 14 & $28 \%$ & 9 & $32 \%$ & 5 & $23 \%$ \\
\hline Total & 50 & $100 \%$ & 28 & $100 \%$ & 22 & $100 \%$ \\
\hline
\end{tabular}

Table-3. Organizational Culture Models Preferred by Macedonian Managers 


\begin{tabular}{|l|c|c|c|c|c|c|}
\hline \multirow{2}{*}{ Executive Level } & \multicolumn{6}{|c|}{ Tercih edilen tarz } \\
\cline { 2 - 7 } & \multicolumn{2}{|c|}{ Traditional } & \multicolumn{2}{c|}{ Entrepreneur } & \multicolumn{2}{c|}{ Flexible } \\
\hline Senior managers & 7 & $58 \%$ & 3 & $25 \%$ & 2 & $17 \%$ \\
\hline Mid-level managers & 5 & $24 \%$ & 7 & $33 \%$ & 9 & $43 \%$ \\
\hline Department managers & 8 & $47 \%$ & 6 & $35 \%$ & 3 & $18 \%$ \\
\hline
\end{tabular}

Table 4. Organizational Culture Preferred by Executive Level

\begin{tabular}{|l|c|c|c|c|c|c|}
\hline \multirow{2}{*}{ Age } & \multicolumn{6}{|c|}{ Preferred style } \\
\cline { 2 - 7 } & \multicolumn{2}{|c|}{ Traditional } & \multicolumn{2}{c|}{ Entrepreneur } & \multicolumn{2}{c|}{ Flexible } \\
\hline $21-30$ & 2 & $18 \%$ & 3 & $27 \%$ & 6 & 55 \\
\hline $31-40$ & 5 & $29 \%$ & 8 & $47 \%$ & 4 & $24 \%$ \\
\hline $41-50$ & 7 & $50 \%$ & 3 & $21 \%$ & 4 & $29 \%$ \\
\hline $50+$ & 5 & $63 \%$ & 3 & $37 \%$ & 0 & $0 \%$ \\
\hline
\end{tabular}

Table 5. Preferred Organizational Culture Age Relationship

Source: Ninko Kostovski, Marjan Bojadjiev and Katerina Buldioska (2015). Leadership Styles and Organizational Culture in Macedonian Companies, Journal of Sustainable Development, Volume 5, Issue 13, Integrated Business Faculty, Skopje, Republic of Macedonia, p. 39.

Looking at the research results, it is possible to summarize the findings obtained as follows:

- In terms of gender; traditional organizational culture seems to be prevalent. However, the situation is slightly different in organizations with female managers. Women managers establish a more entrepreneurial and flexible organizational culture.

- When viewed in terms of age; Traditional culture is common in organizations with managers over the age of 40 .

- Leader's education -especially abroad-affects the choice of organizational culture positively.

- Previous work experience of the leader; It has a positive effect on the choice of organizational culture.

- Education; It is an important factor in choosing the organizational culture practiced by companies. Leaders with a high level of education choose more participatory management styles, while those with a low level of education generally apply autocratic leadership style and resort to traditional methods. 
- Macedonian companies have a more flexible culture, with foreign investors and multinational management teams, and the change in behavior and thinking in these companies is noticeable.

- When the general results of the study are evaluated, it is stated that conservative and traditional culture is common in the country, autocratic management style and non-humanitarian leadership styles are applied. ${ }^{60}$

\section{Slovenia}

Slovenia is the country geographically closest to the west and therefore survived the transition from the Cold War with the least pain. However, the expectation that this situation will also be valid in leadership practices does not coincide with the results we obtained in the researches.

The results of the research conducted by Danijel Pučko and Tomaž Čater among management and engineering students in comparison between Slovenia and the Central European countries in transition provide important data for our study. The research reveals findings and expectations about leadership with the idea that the students in question will be the future organizational leaders (potential leaders ND) of their countries. According to the study, "it is stated that future Slovenian leaders tend to avoid uncertainty more than their Central European counterparts, while potential leaders in the Central European region mostly like charismatic, value-oriented and team-oriented leadership styles, they prefer protective and participatory leadership styles less." According to the research results; It is stated that "Slovenian cultural practices are not similar to an average Central European cultural practice." ${ }^{61}$ Again, it is revealed that Slovenia and Central European countries differ significantly for current cultural practices, values and preferred leadership practices. ${ }^{62}$ Although it is claimed that the roots of behaviors such as gender inequality and socialism, which are common in Slovenia today, date back to the Yugoslavia period, the conclusion reached by the authors after the determination that this will not change the result, summarizes the issue:

It is clear that the transition period of 20 years after the socialist / communist socioeconomic system is not sufficient for a higher level of cohesion and harmony of existing cultures............... There is still a significant difference between the prospective Slovenian leaders of the future and the Central European lead candidates in the same category. ${ }^{63}$

\footnotetext{
${ }^{60}$ Ibid., pp.42-43.

${ }^{61}$ Danijel Pučko \& Tomaž Čater (2011).Cultural Dimensions and Leadership Styles Perceived by Future Managers: Differences between Slovenia and a Cluster of Central European Countries, Organizacija, Volume 44 Number 4, July-August 2011 , p.93

62 Ibid, p.96

${ }^{63}$ Ibid, p.96
} 
Another study is interesting study findings that examine the influence of proverbs in Slovenian work culture and how proverbs shape dynamic leadership styles. It is striking for us that "Slovenian managers generally tend to take risks, generally apply feminine values in leadership and charismatic leadership is dominant" in the research results. ${ }^{64}$

\section{Greece}

Greece is positioned differently by not being a member of the Eastern Block and cooperating with the West from the beginning. In connection with this, early integration steps with the west, such as NATO and EU membership, undoubtedly affected the country's management style. However, we cannot claim that this effect has taken place rapidly from past to present, because the historical culture of the country and the character of this culture, which is affected by the geographical dynamics, prevent us from seeing Greece completely outside the Balkans. The internal turmoil in the country since the 60s and the problems experienced in the EU membership actually show that the country cannot fully integrate with the west. The reflection of this reality on management functions is undoubtedly worth examining. One of the studies that can give an idea on this subject is Bourantas' article. In an empirical study among Greek administrators, examining the relationship between leadership style and satisfaction of needs and organizational commitment, the author found a negative relationship between needs satisfaction and organizational commitment. It is also an important determination that the relationship is stronger in high-level needs than low-level needs. Another important finding of the study is that it found a relationship between leadership styles at the top level and the organizational commitment of subordinates. In the study, it is determined that Greek managers whose supervisors apply a directive (consultant leadership) style have higher organizational commitment and this leadership style is preferred by many people who responded to the research.

In the research by Belias that examines the relationships between leadership styles and job satisfaction in the banking sector, it was found that the leadership style that stands out is transformational leadership. In Aristotle's leadership style research among Greek football coaches, it is emphasized that experienced coaches mostly practice democratic leadership styles, while young and inexperienced coaches are more autocratic and resort to autocratic methods.

The last research we will focus on on Greece is the leadership style research conducted in the media sector. In the study in question, the difficulties of leading these businesses are mentioned because the media sector has both measurable commercial goals and immeasurable social responsibilities, unlike commercial enterprises. The

${ }^{64}$ Gregor Pfajfar, Miha Uhan, Tony Fang, Tjaša Redek (2016). Slovenian Business Culture - How Proverbs Shape Dynamic Leadership Styles, JEEMS, 21(4), pp. 433-457, DOI 10.1688/JEEMS-2016-Pfajfar. 
most important factor in this is that the business leaders in question should adjust the balance between economic and political goals. As a result of the data obtained through the interview method from media leaders, it was found that a mixture of both traditional and transformational leadership styles was applied.

\section{Conclusion}

Both the general point of view and the studies on the basis of countries lead us to the following conclusions about the leadership in the Balkans:

1. Although traditional leadership styles have lost their influence, they are still valid.

2. Balkan culture has autocratic tendencies both from history and with the effect of the Cold War period. Autocratic management still has an important place as a reflection of cultural dimensions such as the fact that the culture of democracy is not yet fully established, avoiding uncertainty in social codes, and power distance.

3. The desire for change with the new generations increases the expectations for a more democratic leadership. With the change in geography, transformational leadership attracts our attention as a leadership style that stands out.

4. It is stated in the literature that while autocratic and task-oriented leadership styles are effective in masculine cultures, democratic and people-oriented leadership styles are dominant in female cultures (Cuadrado, 2003; Cuadrado et al., 2006). The masculine cultural character seen in most of the Balkan countries also manifests itself in the implementation of leadership styles and is in harmony with the literature.

\section{Bibliography}

1. Aktaş, M. and Sargut, A.S. (2011). İzleyicilerin Kültürel değerlerine göre liderliğe duyulan gereksinme nasıl farklılaşır?: Kuramsal bir çerçeve, Amme İdaresi Dergisi, 44(4), pp.145-163.

2. Aycan, Z. and Kanungo, R.N. (2000). Toplumsal Kültürün Kurumsal Kültür ve Insan Kaynakları Uygulamaları Üzerine Etkisi. Inside: Z., Aycan (Ed.), Türkiye’de yönetim, liderlik ve insan kaynakları Uygulamaları (pp. 25-53). Ankara: Türk Psikologlar Derneği Yayınları.

3. Barlı, Ö. (2010). Davranış Bilimleri ve Örgütlerde Davranış, İstanbul: Aktif Yayınevi, p. 355.

4. Batır, F. (2016). Türk Kara Kuvvetleri'nde Kültürel Yönelimler ve Liderlik Iliş̧isi, (Unpublished Masters Thesis), Kara Harp Okulu Savunma Bilimleri Enstitüsü Savunma Yönetimi Ana Bilim Dalı, Ankara. 
5. Bergiel, E. B., Bergiel, B. J. and Upson, J. W. (2012). Revisiting Hofstede's Dimensions: Examining the Cultural Convergence of the United States and Japan, American Journal of Management, Vol. 12(1), pp.69-79.

6. Bojadjiev, M., Kostovski, N. and Buldioska, K. (2015). Leadership Styles in Companies from Republic of Macedonia, Economic Development, Vol.17 Issiue.3, pp.211-222.

7. Den Hartog, D.N., House, R.J., Hanges, P.J., Ruiz-Quintanilla, S.A. and Dorfman, P.W. (1999). Culture specific and cross-culturally generalizable implicit leadership theories: Are attributes of charismatic/transformational leadership universally endorsed? The Leadership Quarterly, 10(2), pp.219-256.

8. Dickson, M.W., Den Hartog, D.N. and Mitchelson, J.K. (2003). Research on leadership in a cross-cultural context: Making progress, and raising new questions. The leadership quarterly, 14(6), pp.729-768.

9. Doğar, N. (2016). Kültür, Kimlik, Etnisite ve Milliyet Kavramları Çerçevesinde Bat Balkanlar: Hofstede Perspektifi, The Journal of Academic Social Science Studies, Number: 52, Winter I 2016, s.410.

10. Edwards, V. and Lawrence, P. (2000) Management in Eastern Europe, UK: Houndsmill.

11. Ercan, Ü. (2010). Liderlerin Kültürel Değer Yönelimleri ve Değerlerin Liderlik Sürecine Etkileri: Türk ve ABD Yöneticileri Üzerine Karşılaş̧tırmalı Bir Araştırma, Unpublished Master's Thesis, Kara Harp Okulu Savunma Bilimleri Enstitüsü Savunma Yönetimi Ana Bilim Dalı, Ankara 2010.

12. Feichtinger, C. and Fink, G. (1998): The Collective Culture Shock in Transition Countries -Theoretical and Empirical Implications. Leadership \& Organization Development Journal. Vol. 19 Iss: 6, pp. 302-308.

13. George, M.J. and Jones, G.R. (2008). Understanding and Managing Organizational Behavior. Pearson: Prentice Hall, Upper Saddle River, New Jersey, p.401.

14. Gupta, V. and Hanges, P.J. (2004). Regional and Climate Clustering of Societal Cultures. In R. J. House, P. J. Hanges, M. Javidan, P. Dorfman ve V. Gupta (Eds.), Leadership, culture, and organizations: The GLOBE study of 62 societies (pp. 178-215). Thousand Oaks, CA: Sage.

15. Hampden-Turner, C.M. and Trompenaars, F. (2008). Building Cross-Cultural Competence: How to Create Wealth from Conflicting Values, Yale University Press.

16. Hofstede, G. and Bond, M.H. (1984). Hofstede's Culture Dimensions: An Independent Validation Using Rokeach's Value Survey, Journal of Cross Cultural Psychology, 15(4), pp.417-433. 
17. Hofstede, G. (1997). Cultures and Organizations: Software of the Mind, 1st edition, McGraw-Hill, USA.

18. Hofsthede, G. (2011). Dimensionalizing Cultures: The Hofstede Model in Context, Online Readings in Psychology and Culture, Article 8.

19. Hofstede, G. (2001). Culture's Consequences: Comparing Values, Behaviors, Institutions, and Organizations Across Nations (2nd ed), Thousand Oaks, CA: Sage Publications.

20. Hofstede, G., Hofstede, G. J., Minkov, M. (2010). Cultures and Organizations: Software of the Mind. Revised and Expanded 3rd Edition. New York: McGrawHill USA.

21. House, R.J., Hanges, P.J., Ruiz-Quintanilla, S.A., Dorfman, P.W, Javidan, M., Dickson, M. and Gupta, V. (1999). Cultural Influences on Leadership and Organizations: Project GLOBE. Advances in Global Leadership, 1(2), pp. 171233.

22. House, R. J. \& Javidan, M. (2004). Overview of GLOBE. In R. J. House, P. J. Hanges, M. Javidan, P. Dorfman, \& V. Gupta (Eds.) Culture, leadership and organizations: The GLOBE study of 62 societies (pp. 219-234). Thousand Oaks, CA: Sage.

23. Hurduzeu, R.-E. (2015). Culture and Leadership: The Case of Romania, The Romanian Economic Journal, Year XVIII, No.56, pp.119-134.

24. Janićijević, N. (2008). Organizaciono ponašanje, Datastatus, Belgrad.

25. Jung, D.I. and Avolio, B.J. (1999). Effects of leadership style and followers' cultural orientation on performance in group and individual task conditions. Academy of management journal, 42(2), pp. 208-218.

26. Kabasakal, H.; Dastmalchian, A.; Karaçay, G. and Bayraktar, S. (2012). Leadership and culture in the MENA region: An analysis of the GLOBE Project, Journal of World Business, 47(4), pp. 519-529.

27. Koçel, T. (2010). İşletme Yöneticiliği. İstanbul: Beta Basım Yayım Dağıtım A.Ş., p. 569.

28. Kostovski, N., Bojadjiev, M. and Buldioska, K. (2015). Leadership Styles and Organizational Culture in Macedonian Companies, Journal of Sustainable Development, Volume 5, Issue 13, Integrated Business Faculty, Skopje, Republic of Macedonia, p. 39.

29. Luca A. (2005) Employeescu, O scurtă caracterizare a angajatului roman, Bucureşti, Editura Interact.

30. Musaraj, A., \& Gerxhi, J. (2010). Communication and Ethical Behavior in the Public Service. Academicus International Scientific Journal ISSN, 2079-3715. 
31. Musaraj, A. (2019). Technocracy and the questionable moral philosophy of management. A Southeast Europe inside. Academicus International Scientific Journal, 10(19), 37-48.

32. Pfajfar, G., Uhan, M., Fang, T. and Redek, T. (2016). Slovenian Business Culture - How Proverbs Shape Dynamic Leadership Styles, JEEMS, 21(4), pp. 433-457, DOI 10.1688/JEEMS-2016-Pfajfar.

33. Pržulj, Ž. and Vukelić, G. (2011). Cultural Barriers to Serbia Joining the European Union, pp.118-132, Inside: Mirjana Radovic Markovic \& Srdjan Redzepagic \& João Sousa Andrade \& Paulino Teixeira (ed.), 2011. "Serbia and the European Union: Economic Lessons from the New Member States," Books, Institute of Economic Sciences, edition 1, volume 1.

34. Pučko, D. and Čater, T. (2011).Cultural Dimensions and Leadership Styles Perceived by Future Managers: Differences between Slovenia and a Cluster of Central European Countries, Organizacija, Volume 44 Number 4, July-August 2011, p.93.

35. Smith, P.B., Peterson, M.F. and Misumi, J. (1994). Event management and work team effectiveness in Japan, Britain and the USA. Journal of Occupational and Organizational Psychology, 67(1), pp.33-43.

36. Steyrer, J., Hartz, R. and Schiffinger, M. (2006). Leadership in transformation between local embeddedness and global challenges, Journal of East European Management Studies, Vol. 11, No. 2, pp. 113-139.

37. Tabak, A. ve Sığrı, Ü. (2014). Liderlik. İçinde: Ü.Sığrı ve S. Gürbüz (Ed.), Örgütsel davranış (pp. 373-429), İstanbul, Beta Yayınları.

38. Todorov, K. and Kereziev, I. (2013). Leadership Transfer and the Successors Preparation in Bulgarian Family Enterprises, Economic Alternatives, Issue 2, pp.5-20.

39. Todorova, M. (2004). What is or is there a Balkan culture, and do or should the Balkans have a regional identity?, Southeast European and Black Sea Studies, 4:1, pp.175-185.

40. Vukonjanski, J., Nikoli, M., Hadži, O., Terek, E. and Nedeljkovi, M. (2012). Relationship between GLOBE organizational culture dimensions, job satisfaction and leader-member exchange in Serbian organizations, Journal of East European Management Studies (JEEMS), pp. 333-368.

41. Yan, J. and Hunt, J.G.J. (2005). A Cross Cultural Perspective on Perceived Leadership Effectiveness, International Journal of Cross Cultural Management, 5(1), pp.49-66.

42. Yeşilyurt, P. (2007). Türk ve Italyan Yöneticilerinin Liderlik Tarzları: Türkiye'de Faaliyet Gösteren Türk-italyan Ortak Girişimlerinde Bir Uygulama, Unpublished 
Unpublished Master's Thesis, Çukurova Üniversitesi Sosyal Bilimler Enstitüsü İşletme Anabilim Dalı, Adana, pp.43-45.

43. Zogjani, A., Llaci, S. and Elmazi, E. (2014). The Role of Power in Effective Leadership and Followership: The Albanian Case, Romanian Economic and Business Review, Vol. 9, No. 1, pp.89-103. 